\title{
THE EPIDEMIOLOGIC PROFILE AND PREVALENCE OF CARDIOPATHY IN Trypanosoma cruzi INFECTED BLOOD DONOR CANDIDATES, LONDRINA, PARANÁ, BRAZIL
}

\author{
Divina Seila de OLIVEIRA-MARQUES(1), Ana Maria BONAMETTI(2), Tiemi MATSUO(3) \& Francisco GREGORI JUNIOR(4)
}

\begin{abstract}
SUMMARY
To describe the epidemiologic profile and prevalence of cardiopathy in 163 Trypanosoma cruzi serum positive blood donor candidates, a descriptive study was carried out between August, 1996 and November, 1997 at the Londrina State University Chagas Disease Outpatient Clinic. The profile found was: young, average age $42.95 \pm 8.62$ years; male (65\%); Caucasian (84\%); low level of schooling; low family income; agricultural worker (26\%); born in the state of Paraná (67\%); from rural areas (85\%); migrated to the city $(85 \%)$; and the vector as the main mechanism of transmission. During the clinical characterization a chronic cardiac form was found in $38 \%$ of the patients and classified as cardiac suggestive form in $21 \%$ and little suggestive of Chagas disease in $17 \%$. No significant difference was found among age group distribution, sex and the presence of cardiac symptoms in patients with or without cardiopathy. This study emphasizes the importance of expanding medical services to areas with a greater prevalence of infected individuals, in a hierarchical manner and aiming at decentralization.
\end{abstract}

KEYWORDS: Chagas Disease; American Trypanosomiasis; Epidemiology; Myocardiopathy.

\section{INTRODUCTION}

Chagas disease is a parasitosis caused by the protozoan Trypanosoma cruzi. It is endemic in the Americas, from central Mexico to the south of Argentina and Chile ${ }^{12,34}$. It is estimated that the number of infected individuals in Brazil is around three million and it is one of the greatest public health problems in the Country ${ }^{1,13}$.

Means to control the main route of transmission - vectorial - have been available since the $40 \mathrm{~s}$, following the proven effectiveness of treatment with insecticides to eliminate the vector in a direct way or indirectly through improvement of living conditions in rural areas ${ }^{34}$. Prior selection of blood donors through serologic screening is the main strategy to prevent transfusion transmission - the second most important path of transmission - which was introduced as a health policy in Brazil in $1969^{2}$. However, with the emergence of acquired immunodeficiency virus infections, a complete review of the policy for blood and hemoderivates was carried out in Brazil. The Ministry of Health recommended that blood from all donors should be tested for antiTrypanosoma cruzi antibodies using at least two serologic techniques ${ }^{2,36}$.

With these measures, control by the hemotherapy services has been elevated to over $80 \%$ throughout Brazil and the median of infected donor candidates is below $0.8 \%{ }^{14}$. In Paraná, the effectiveness of these measures was demonstrated from 1985, when an analysis of 1,977 blood donor candidates from 33 cities of the state showed a seropositivity of $7.2 \%{ }^{29}$. Furthermore, according to the Coordination of Blood and Hemoderivates of the Ministry of Health this figure for the state as whole had decreased to $0.86 \%$ in $1995^{\circ}$. In the city of Londrina, data collection carried out by various authors in the years of 1958, 1975, 1996 and 1998, found a decreasing seroprevalence of $6.92 \%, 7.49 \%, 1.4 \%$ and $1.3 \%$, respectively $y^{4,531,32}$.

Nowadays, with the main way of transmission under control, the principal concern is regarding assistance to infected individuals, particularly their situation in the job market, the social services involved and the necessity for adequate medical care ${ }^{18}$. The assistance to rejected donors referred by hemotherapy services is a special concern. These donors present peculiarities such as the presence of inconclusive serologic screening, or a confirmed diagnosis in apparently healthy individuals, that might or might not have clinical implications - of which cardiopathy is the most frequent ${ }^{15,16,19}$. It is not the responsibility of hemotherapy services to clinically attend these patients; therefore there is a need to provide related care services in various centers ${ }^{23}$.

Faced with a previous study that affirmed that $80 \%$ of infected patients could receive medical care in primary care services ${ }^{18}$, a clinical epidemiologic study in a sample of our population was proposed. The aim of this study was to set goals for the improvement of such services 


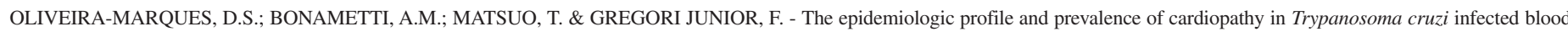
donor candidates, Londrina, Paraná, Brazil. Rev. Inst. Med. trop. S. Paulo, 47(6):321-326, 2005.

and to assess the possibility of decentralization, through determination of the patients" characteristics.

\section{MATERIAL AND METHODS}

Design: A descriptive study carried out through the review of medical records and dossiers of 163 blood donor candidates that presented positive serologic reaction to Trypanosoma cruzi, referred by hemotherapy services and attended at the Londrina State University Chagas Disease Outpatient Clinic from August 1996 to November 1997.

\section{Data collection and mensuration}

Personal data: Hospital record, age, gender, race, educational level, monthly family income, profession, origin and present residency, classified by state of origin. The State of Paraná was divided into geographic micro and meso regions, according to the Brazilian Institute of Geography and Statistics ${ }^{20}$.

Epidemiologic data: The way of infection transmission was evaluated by knowledge of the vector, residency or travel in endemic areas, mother or other family member with Chagas disease and history of blood transfusion. The patients were also asked whether they had effectively donated blood prior to the present diagnosis of T. cruzi infection.

Serologic diagnosis: Carried out through indirect immunofluorescence techniques ${ }^{9}$ (LIOSERUM, São Paulo, Brazil and LABORCLIN, Paraná, Brazil); indirect hemagglutination ${ }^{21,26}$ (EBRAM, São Paulo, Brazil) and immunoenzymatic assay ${ }^{35}$ (ABBOTT, São Paulo, Brazil). The individuals that presented at least two positive reactions were considered infected.

Clinical data: Patients that complained of at least one of the following were considered symptomatic: dyspnea, palpitations, precordialgia, fainting and/or dizziness. All patients were submitted to conventional electrocardiogram in 12 derivations with long D2 (EKG) and thorax radiography at posteroanterior incidence. EKG with alterations characteristic of Chagas disease were considered to be those that revealed the presence of: complete right bundle branch block, left anterior hemiblock, A-V block, multifocal ventricular extrasystoles and sinusal bradycardia connected to ventricular repolarization alteration or to other alterations, according to the method used by the National Electrocardiographic Survey on Chagas Disease ${ }^{24}$. To evaluate the presence of cardiomegaly, analysis of the cardiothoracic index (I:CT) was used in thorax radiography, considered indicator of cardiomegaly when greater than $50 \%$. The cardiac form was defined by the presence of electrocardiographic alterations and/or cardiomegaly in the thorax radiography. The cardiac form was classified as suggestive of Chagas disease when characteristic electrocardiographic alterations were present, and little suggestive of Chagas disease when other electrocardiographic alterations were identified.

Statistical analysis: The data was stored in the software Epi Info release 6.04 and analyzed with SAS software - Statistical Analysis System release 6.11. In the analysis, descriptive statistics were used and Chi-square test applied to compare proportions. Statistical significance was set at the $5 \%$ level.

\section{RESULTS}

Age varied from 18 to 63 years, with a mean of 42.5 and standard deviation of 8.62 years. It was observed that $46 \%$ of the patients were in the 40-50 y age group. Most of the patients were male - $106(65 \%)$, white - $137(84 \%)$, illiterate - $23(14 \%)$ or with incomplete basic education - $109(67 \%)$ and with monthly family income up to three minimum wages - 134 (82\%). Agriculture was the professional area most referred to, followed by self-employed, identified in $42(26 \%)$ and $31(19 \%)$ patients, respectively. Most of the patients were born in the state of Paraná - 108 (66\%), followed by Minas Gerais - 23 (14\%), São Paulo - 20 (12.5\%) and other states - 12 (7.5\%). It was observed that $138(85 \%)$ patients came from rural areas. In the evaluation of the origin of 108 patients from the state of Paraná, 91 (84\%) come from the North Pioneer mesoregion, mainly from the microregions of Wenceslay Braz - 41 (38\%), Assaí - 22 (20\%) and Cornélio Procópio $20(18.5 \%)$. Only $6(5.5 \%)$ come from the microregion of Londrina. All 163 patients currently reside in the state of Paraná, the majority in the urban area - $138(85 \%)$, proportionally distributed among the North Pioneer - $82(50.4 \%)$ and North Central - 80 (49\%) mesoregions, with predominance of the microregion of Londrina - 64 (39\%), followed by Wenceslay Braz - 44 (27\%).

Regarding the presence of symptoms, it was observed that 98 (60\%) patients presented symptoms and $65(40 \%)$ were asymptomatic. In the EKG analysis, 107 (65\%) did not present alteration. Out of $56(34.5 \%)$ patients with electrocardiographic alterations (Table 1), 29 (18\%) presented alterations considered characteristic of Chagas disease and $27(16.5 \%)$ presented other alterations. It was observed that $145(89 \%)$ patients presented normal cardiac area and $18(11 \%)$ presented cardiomegaly in the thorax radiography. Analysis of the

Table 1

Distribution of the electrocardiographic alterations in 56 of the 163 patients studied

\begin{tabular}{lrr}
\hline Alterations in electrocardiogram & No. & $\%$ \\
\hline VRA & 17 & 30.0 \\
SB & 8 & 14.0 \\
CRBB and LAH & 8 & 14.0 \\
CRBB & 6 & 11.0 \\
LAH & 3 & 5.0 \\
VE & 2 & 3.5 \\
CRBB, LAH and VRA & 2 & 3.5 \\
SB and LAH & 2 & 3.5 \\
LAH and VRA & 2 & 3.5 \\
$1^{\circ}$ AVB & 1 & 2.0 \\
$2^{\circ}$ AVB & 1 & 2.0 \\
$1^{\circ}$ AVB, LAH and VRA & 1 & 2.0 \\
$2^{\circ}$ AVB, LAH and CRBB & 1 & 2.0 \\
SB and CRBB & 1 & 2.0 \\
SB and VE & 1 & 2.0 \\
\hline TOTAL & 56 & 100.0 \\
\hline
\end{tabular}

CRBB: complete right bundle branch block; LAH: left anterior hemiblock; $1^{\circ}$ AVB: $1^{\text {st }}$ atrioventricular block; $2^{\circ}$ AVB: $2^{\text {nd }}$ atrioventricular block; SB: sinusal bradycardia; VE: ventricular extrasystoles; VRA: ventricular repolarization alteration. 

donor candidates, Londrina, Paraná, Brazil. Rev. Inst. Med. trop. S. Paulo, 47(6):321-326, 2005.

electrocardiogram and thorax radiography for clinical characterization showed that $62(38 \%)$ patients presented electrocardiographic and/or radiologic alterations, which characterized the presence of the cardiac form. Out of these, $35(21 \%)$ were characterized as suggestive of cardiac form and $27(16.5 \%)$ as cardiac form little suggestive of Chagas disease (Fig. 1).

When comparing the clinical forms of Chagas disease according to age group, the chronic cardiac form was less frequent in individuals under 30 years of age $(2 \%)$, despite the fact that a proportional distribution of clinical forms in different age groups was observed ( $p$ $=0.210$ ) (Fig. 2). It was also observed that, when comparing the clinical form and gender, the chronic cardiac form was present in 19/57 (33\%) female patients and in 43/106 (41\%) male patients. The results were not statistically significant ( $\mathrm{p}=0.364$ ) (Fig. 3). When the clinical form of Chagas disease was compared to the presence of symptoms, it was evident that in patients with chronic cardiac form, $45 \%$ presented symptoms and $55 \%$ presented no symptoms. In those patients with

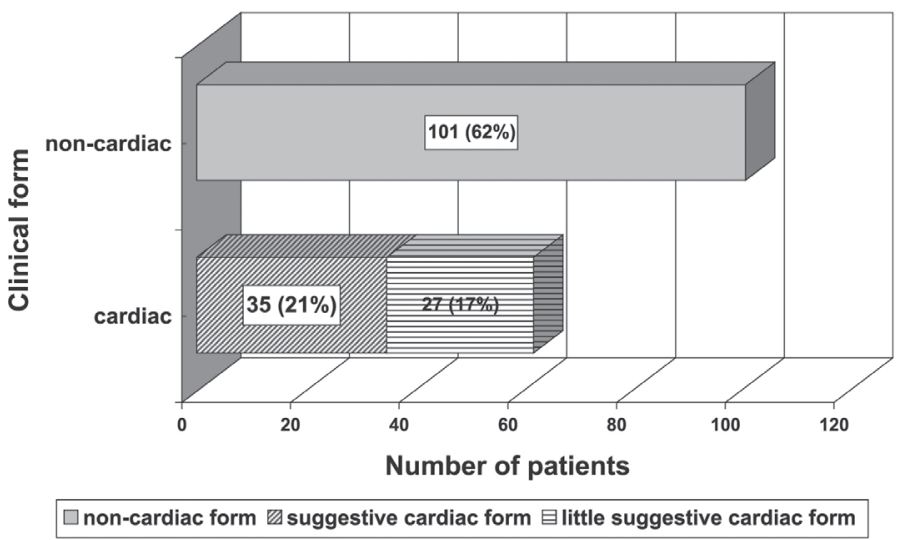

Fig. 1 - Distribution of the 163 studied patients, in accordance with the clinical form of Chagas disease.

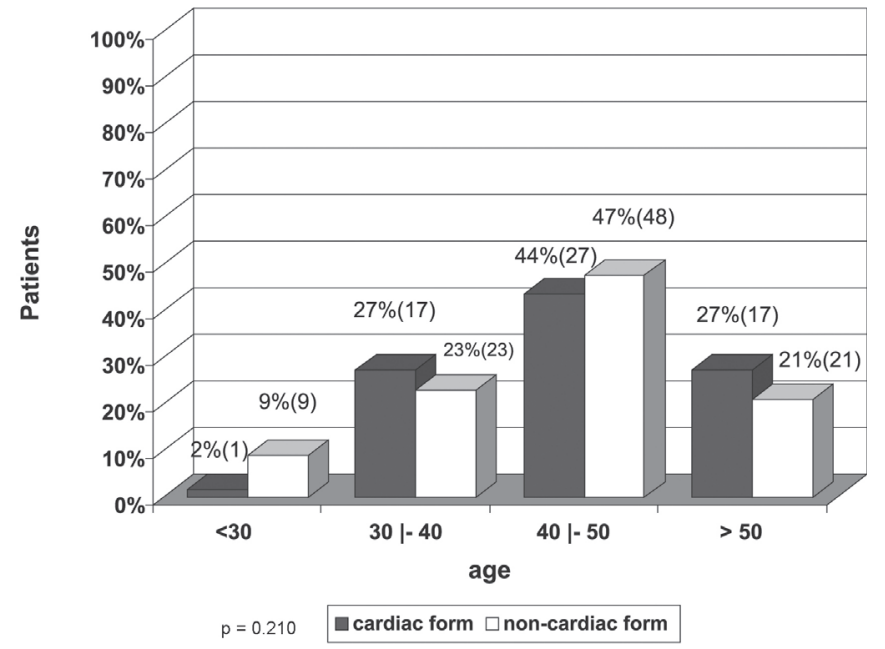

Fig. 2 - Percentage distribution of the patients according to age and clinical form of Chagas disease. chronic non-cardiac form, 37\% presented symptoms and $63 \%$ presented no symptoms. When comparing these distributions, statistical significance was not observed $(\mathrm{p}=0.280)$ (Fig. 4).

\section{DISCUSSION}

About one hundred years after its description, Chagas disease remains a serious public health problem. Its epidemiologic and clinical aspects have been emphasized and continue to be of great value for the planning of prophylactic actions - seen as a great weapon against this infection $^{12}$.

The epidemiologic profile of the blood donor candidate infected by Trypanosoma cruzi revealed a young, male and white individual with a low level of education. These results were similar to those published by GONTIJO et al. (1996), with the exception of race, as

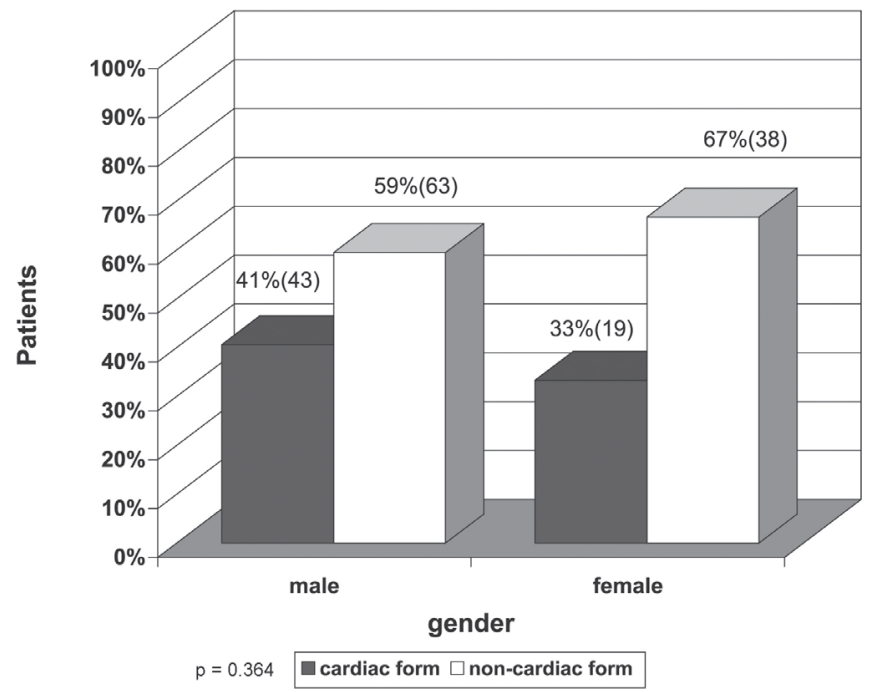

Fig. 3 - Percentage distribution of the patients according to gender and clinical form of Chagas disease.

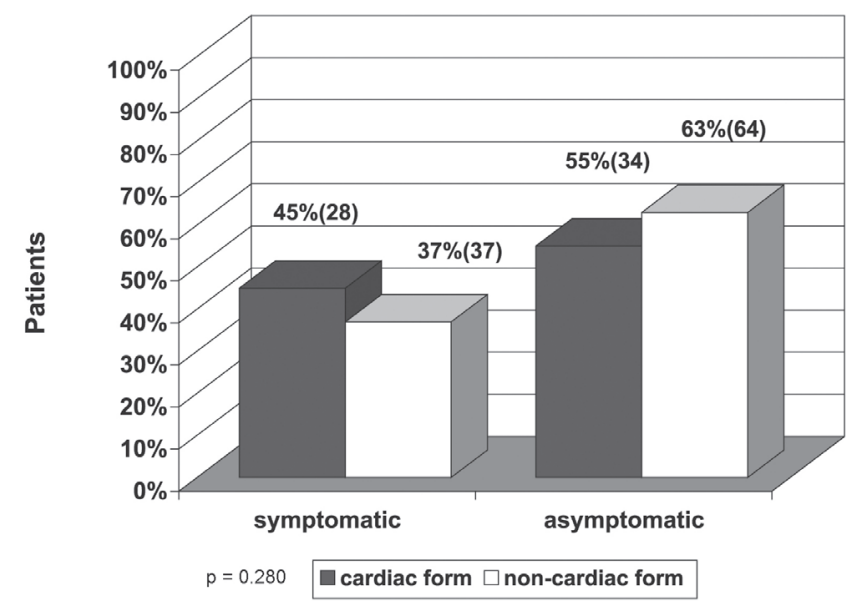

Fig. 4 - Percentage distribution of the patients according to the presence of symptoms and clinical form of Chagas disease. 


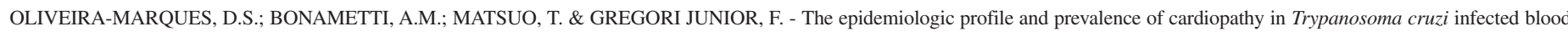
donor candidates, Londrina, Paraná, Brazil. Rev. Inst. Med. trop. S. Paulo, 47(6):321-326, 2005.

the author found a predominance of mulatto or black patients $(60 \%)$. This difference may be explained by regional variations in racial distribution. According to GUARIENTO et al. (1996), the predominance of males is explained by cultural differences in the practice of blood donation that attributes male individuals the role of donor par excellence.

Other identified aspects were the prevalence of low monthly family income and agriculture as the professional area. Previous observations had already revealed that the Chagas patient is generally an individual with low professional qualification and incomplete education, who works in functions that require greater physical effort and that do not offer adequate conditions of remuneration ${ }^{16}$.

Regarding origin, the majority was born in the rural area $(85 \%)$, coming from the state of Paraná - 108 (66\%), followed by 23 (14\%) from Minas Gerais, 23 (14\%) from São Paulo and 12 (7.5\%) from other states. Of 108 patients from the state of Paraná, the majority (84\%) came from the North Pioneer mesoregion. These characteristics are related to aspects of colonization and development of the regions considered endemic in the State, since, from the XIX Century on, the north region has differed from the other regions due to the development of coffee culture, started by migrants from the states of Minas Gerais and São Paulo ${ }^{7}$.

The migrating component was evident in this study, especially regarding rural-urban migration, since, when the present home was analyzed, all patients lived in the state of Paraná and the majority (85\%) in an urban area. These results are connected to the regional transformations that occurred within the state, mainly following changes in agricultural production. From 1960 on, coffee plantations began to be replaced by other mechanized cultures such as soy and wheat, which led to migration to cities that required a larger labor force due to the industrialization process $^{8}$. This intense rural-urban migratory process was also observed in studies carried out with Chagas patients in other regions of the Country such as the state of São Paulo and Minas Gerais ${ }^{3,17,18}$.

Most of the patients (142/87\%) evaluated in this study were from regions endemic for Chagas disease and born in a rural area. This fact suggests that the predominant mechanism of transmission was vectorial. Out of the remaining 21 patients, $10(6 \%)$ had a history of transfusion of blood or hemoderivates, characterizing the possibility of transfusion transmission and $6(4 \%)$ were children of mothers with positive serology for Chagas disease, a fact suggesting the possibility of congenital transmission. Five (3\%) patients were born and always resident in an urban area and denied a previous history of blood transfusion or mother with positive serology for Chagas disease, consequently it was impossible to characterize the transmission mechanism.

From 163 patients, 39 (24\%) reported having already donated blood, out of which 14 (34\%) referred to negative result of previous serology. Some authors have already demonstrated the possibility of false negative results of serologic reactions to the diagnosis of Trypanosoma cruzi infection in proven infected individuals, mainly when techniques with low sensitivity and specificity were used, such as the complement fixation reaction ${ }^{10}$.

Electrocardiographic alterations were presented by $56 / 163(34 \%)$ individuals although in only 29 (18\%) patients the electrocardiographic wave detected alterations considered characteristic of Chagas cardiopathy. According to MACÊDO (1993), in the National Electrocardiographic Survey to evaluate the prevalence of Chagas cardiopathy, the prevalence of electrocardiographic alterations in individuals seropositive for Trypanosoma cruzi infection was initially of $37.4 \%$, but fell $24.4 \%$, when only the alterations characteristic of Chagas cardiopathy were considered. In the state of Paraná, the same survey detected that $23 \%$ of the seropositive patients presented electrocardiographic alterations characteristics of Chagas cardiopathy.

When the electrocardiographic and radiologic alterations are analyzed as a whole, in $35(21 \%)$ patients, the presence of characteristic electrocardiographic alterations and/or the presence of cardiomegaly in the thorax radiography characterizing the cardiac form suggestive of Chagas disease was observed; in 27 (17\%) patients, noncharacteristic electrocardiographic alterations were observed, characterizing a cardiac form little suggestive of Chagas disease. When considering all the electrocardiographic and radiologic alterations detected, the prevalence of Chagas cardiopathy was 38\% (62 patients). Studies carried out on samples of blood donor candidates seropositive for Trypanosoma cruzi infection have detected prevalence of Chagas cardiopathy between 30.0 and $56.7 \%^{10,18,22,27,33}$. This variation may be related to a lack of standardization of the adapted criteria in electrocardiographic analysis or to regional variations in the prevalence of this infection.

The analysis of the clinical form of patients evaluated in the present study revealed that $65(40 \%)$ were symptomatic; the most frequent reported symptom was dyspnea in $45(28 \%)$, followed by palpitation in $34(21 \%)$, dizziness in $26(16 \%)$, precordialgia in $24(15 \%)$ and fainting in $6(4 \%)$. When comparing the patients with Chagas cardiopathy to those without this illness, regarding the presence of symptoms, it was verified that there was no statistically significant difference between both groups. According to MARIN-NETO, SIMÕES \& SARABANDA (1997), the natural history of Chagas disease is prodigal in phases and clinical forms and there is flagrant dissociation between the presence of symptoms and objective signs of organic damage.

The evaluation according to age showed that there was a greater frequency of cardiopathy in patients who were 40 years old and older, however, without statistical significance. According to PRATA et al. (1993), the greater frequency of electrocardiographic alterations in the elderly may be related to longer time evolution of the Chagas cardiopathy and to the concomitance of other affections such as systolic arterial hypertension and coronary insufficiency. This difference was probably not detected statistically in our study due to the sample size.

According to PEREIRA-BARRETTO et al. (1993), the prevalence of Chagas cardiopathy is greater and the prognosis worse in male patients seropositive for Trypanosoma cruzi infection. No difference was found regarding the prevalence of cardiopathy and gender in our study.

In view of the present results and according to the principle that attendance of Chagas patients should take place preferentially close to where they live, we concluded that human resources training and 


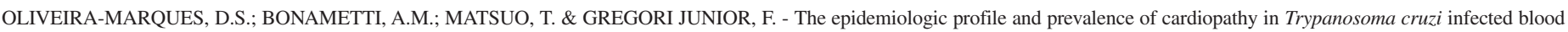
donor candidates, Londrina, Paraná, Brazil. Rev. Inst. Med. trop. S. Paulo, 47(6):321-326, 2005.

qualification are necessary, along with the organization of services with diagnostic support to provide good quality serology and basic complementary exams such as electrocardiogram and thorax radiography. These should be provided in health services already existent in the regions with great occurrence of infected individuals requiring assistance at primary level. Since interinstitutional integration is a basic characteristic in the operationalization of the model of health care in Chagas disease, the maintenance of a Service at the Londrina State University Clinics Hospital is necessary, to serve as a reference center for patients who need specialized care.

\section{RESUMO}

\section{Perfil epidemiológico e prevalência de cardiopatia em candidatos a doador de sangue infectados por Trypanosoma cruzi, Londrina, Paraná, Brasil}

Objetivando-se traçar o perfil epidemiológico e a prevalência de cardiopatia, realizou-se estudo descritivo em 163 candidatos a doador de sangue infectados por Trypanosoma cruzi, atendidos no período de agosto de 1996 a novembro de 1997 no ambulatório de doença de Chagas do Hospital de Clínicas da Universidade Estadual de Londrina. O perfil epidemiológico foi de paciente jovem, média de idade de 42,95 $\pm 8,62$ anos, sexo masculino $(65 \%)$, raça branca $(84 \%)$, baixa escolaridade, baixa renda familiar, agricultor $(26 \%)$, natural do estado do Paraná $(67 \%)$, de zona rural $(85 \%)$, residindo atualmente em zona urbana (85\%), sendo o vetorial o principal mecanismo de transmissão. A forma crônica cardíaca, encontrada em $38 \%$ foi classificada em forma cardíaca sugestiva de doença de Chagas em $21 \%$ e pouco sugestiva em $17 \%$ dos pacientes. Não houve diferença significativa na distribuição da faixa etária, sexo e presença de sintomas cardíacos em relação aos pacientes com ou sem cardiopatia. $\mathrm{O}$ estudo ressalta a importância da expansão de serviços de atendimento em regiões de maior ocorrência de indivíduos infectados e manutenção de serviços de referência, para oferecer atendimento de forma descentralizada e hierarquizada.

\section{REFERENCES}

1. AKHAVAN, D. - Análise de custo-efetividade do programa de controle da doença de Chagas no Brasil: relatório final. Brasília, OPAS, 2000.

2. ANDRADE, A.L.; ZICKER, F. \& MARTELLI, C.M. - An epidemiological approach to study congenital Chagas' disease. Cad. Saúde públ. (Rio de J.), 10(supl. 2): 345$351,1994$.

3. ANTUNES, C.M.; CHIARI, C.A. \& MEYER, M.A. - Epidemiologia da doença de Chagas em Belo Horizonte, MG, Brasil. Rev. Soc. bras. Med. trop., 17(supl.): 69, 1984.

4. BALDY, J.L.; TAKAOKA, L.; PEREIRA, J.D.; CALIXTO, A.A. \& DUARTE, E.F. Prevalência da infecção por Trypanosoma cruzi, em 1975, em dois bancos de sangue de Londrina, Paraná, Brasil. Rev. Saúde públ. (S. Paulo), 12: 409-416, 1978.

5. BONAMETTI, A.M.; CASTELO-FILHO, A.; RAMOS, L.R.; BALDY, J.L. \& MATSUO, T. - Infecção por Trypanosoma cruzi em candidatos a doador de sangue. Rev. Saúde públ. (S. Paulo), 32: 566-571, 1998.

6. BRASIL. Ministério da Saúde. Coordenação de Sangue e Hemoderivados - Trypanosoma cruzi. Brasília, Ministério da Saúde, 1995.

7. BRASIL. Ministério da Saúde. Fundação Nacional de Saúde. Coordenação regional do Paraná - Programa de controle de doença de Chagas no Paraná. Curitiba, Ministério da Saúde, 1996.
8. CAMARA, M.R.G. - Transformações agrícolas e êxodo rural no Paraná na década de 70. São Paulo, 1986. (Dissertação de Mestrado - Faculdade de Economia e Administração da Universidade de São Paulo).

9. CAMARGO, M.E. - Fluorescent antibody test for the serodiagnosis of American Trypanosomiasis. Technical modification employing preserved culture forms of Trypanosoma cruzi in a slide test. Rev. Inst. Med. trop. S. Paulo, 8: 227-234, 1966.

10. CAMPOS, C.; REZENDE, J.M. \& RASSI, A. - Prevalência da doença de Chagas no Banco de Sangue do Hospital das Clínicas de Goiânia. Possibilidade de falha da reação de Guerreiro e Machado na seleção de doadores. Rev. Soc. bras. Med. trop., 9: $165-174,1975$

11. CAMPOS, D.E.; RASSI, S.; VAZ, M.G. et al. - Serviço de atenção ao doador excluído por doença de Chagas no Hospital das Clínicas de Goiânia. Perfil clínico da população atendida em 2 anos. Rev. Soc. bras. Med. trop., 29(supl. 2): 143-144, 1996.

12. CHAGAS, C. - Nova tripanozomiaze humana. Mem. Inst. Oswaldo Cruz, 1: 159-218, 1909.

13. DIAS, J.C. - A doença de Chagas e seu controle na América Latina. Uma análise de possibilidades. Cad. Saúde públ. (Rio de J.), 9: 201-209, 1993.

14. DIAS, J.C. \& COURA, J.R. - Epidemiologia. In: DIAS, J.C.P. \& COURA, J.R. Clínica e terapêutica da doença de Chagas. Rio de Janeiro, FIOCRUZ, 1997. p. 33-65.

15. GARZON, S.A.; LORGA, A.M. \& NICOLAU, J.C. - Eletrocardiografia na cardiopatia chagásica. Rev. Soc. Cardiol. (S. Paulo), 4: 133-143, 1994.

16. GÓES, A.L. \& GUARIENTO, M.E. - Perfil psicológico do candidato à doação de sangue, soropositivo para infecção pelo T.cruzi. Estudo realizado em Campinas, SP. Rev. Soc. bras. Med. trop., 29: 146-149, 1996.

17. GOLDBAUM, M. - Saúde e trabalho. A doença de Chagas no setor industrial. São Paulo, 1981. (Tese de Doutorado - Faculdade de Medicina da Universidade de São Paulo).

18. GONTIJO, E.D.; ROCHA, M.O. \& TORQUATO DE OLIVEIRA, U. - Perfil clínicoepidemiológico de chagásicos atendidos em ambulatório de referência e proposição de modelo de atenção ao chagásico na perspectiva do SUS. Rev. Soc. bras. Med. trop., 29: 101-108, 1996.

19. GUARIENTO, M.E.; ALMEIDA, E.A. \& GILLI, S.C. - Perfil do doador de sangue infectado pelo T. cruzi em Campinas (SP), avaliado a partir do grau de risco para a enfermidade de Chagas e do gênero. Rev. Soc. bras. Med. trop., 29(supl. 2): 27-29, 1996.

20. INSTITUTO BRASILEIRO DE GEOGRAFIA E ESTATÍSTICA - Sinopse preliminar do Censo Demográfico. Rio de Janeiro, IBGE, 1991. v. 6, No. 20. p. 15-35.

21. KNIERIM, F. \& SAAVEDRA, P. - Técnica de la reacción de hemaglutinación aplicada al diagnóstico serológico de las parasitosis. Bol. chil. Parasit., 21: 39-43, 1966.

22. LOPES, M.H. - Doador de sangue infectado: doença de Chagas. Rev. Soc. bras. Med. trop., 29(supl. 2): 29-32, 1996.

23. LUQUETTI, A.O. - Serviços de atendimento ao doador com doença de Chagas no Brasil Rev. Soc. bras. Med. trop., 29(supl. 2): 137, 1996.

24. MACÊDO, V. - Inquérito eletrocardiográfico nacional para doença de Chagas. Rev. Soc. bras. Med. trop., 26(supl. 2): 12-13, 1993.

25. MARIN-NETO, J.A.; SIMÕES, M.V. \& SARABANDA, A.V.L. - Doença cardíaca no indivíduo assintomático com moléstia de Chagas. Rev. Soc. Cardiol. (S. Paulo), 7: 726-734, 1997.

26. MIDDLEBROOK, G. \& DUBOS, R.J. - Specific serum agglutination of erythrocytes sensitized with extracts of tubercle bacilli. J. exp. Med., 88: 521-528, 1948. 


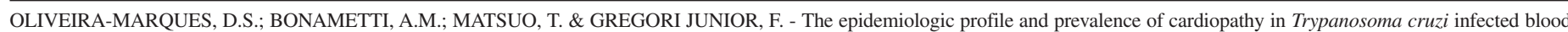
donor candidates, Londrina, Paraná, Brazil. Rev. Inst. Med. trop. S. Paulo, 47(6):321-326, 2005.

27. MORAES-SOUZA, H.; MIZIARA, L.J.; MORAIS, C.A. et al. - Análise de 122 chagásicos doadores de sangue. Aspectos clínicos, terapêuticos e trabalhistas. Rev. Soc. bras. Med. trop., 17(supl.): 80, 1984.

28. PEREIRA BARRETTO, A.C.; ARTEAGA, E.; MADY, C. et al. - Sexo masculino. Fator prognóstico na Doença de Chagas. Arq. bras. Cardiol., 60: 225-227, 1993.

29. PONTELlO, R.; REICHE, E.M. \& CABRERA, E.J. - Prevalência da infecção por Trypanosoma cruzi, Treponema pallidum e vírus da hepatite B, no período de 1980 a 1983, avaliada através de testes sorológicos, em 1977 candidatos a doadores de sangue de 33 cidades do estado do Paraná. Semina (Londrina), 6: 87-92, 1985.

30. PRATA, S.P.; CUNHA, D.F.; CUNHA, S.F. et al. - Prevalência de alterações eletrocardiográficas em 2000 pacientes chagásicos idosos e não idosos. Arq. bras. Cardiol., 60: 369-372, 1993.

31. QUEIRÓZ, J.A. \& PASCUAL, J. - Contribuição ao estudo da doença de Chagas no Norte do Paraná. Rev. méd. Paraná, 27: 27-30, 1958.

32. REICHE, E.M.; INOUVE, M.M.Z.; PONTELLO, R. et al. - Seropositivity for antiTrypanosoma cruzi antibodies among blood donors of the Hospital Universitário Regional do Norte do Paraná, Londrina, Brazil. Rev. Inst. Med. trop. S. Paulo, 38: 233-240, 1996
33. RigOU, D.G.; GUllone, N.; CARNEVAli, L. \& DE ROSA, A.F. - Chagas asintomático. Hallazgos electrocardiográficos y ecocardiográficos. Medicina (B. Aires), 61: 541-544, 2001.

34. SCHMUNIS, G.A. - Tripanossomíase americana: seu impacto nas Américas e perspectivas de eliminação. In: DIAS, J.C.P. \& COURA, J.R. Clínica e terapêutica da doença de Chagas. Rio de Janeiro, FIOCRUZ, 1997. p. 11-23.

35. VOLLER, A.; DRAPER, C.; BIDWELL, D.E. \& BARTLETT, A. - Microplate enzymelinked immunosorbent assay of Chagas' disease. Lancet, 22: 426-428, 1975.

36. WANDERLEY D.M.V.; GONZALES, T.T.; PEREIRA, M.S. et al. - Controle da hemoterapia e da doença de Chagas transfusional: 1988 e 1990. Rev. Saúde públ. (S.Paulo), 27: 430-435, 1993.

Received: 2 May 2005

Accepted: 21 July 2005 